\title{
The Emblems of the Album of the Liubljana Noble Society of St Dismas: Context, Sources, Originality
}

\author{
Keywords: Album of The Ljubljana Noble Society of St Dismas, Filippo Picinelli, \\ Mundus Symbolicus, Andrea Alciati, Emblematum liber, Renaissance and Baroque \\ emblems, iconography, Janez Gregor Dolničar, Andrej Trost
}

DOI: 10.4312/ars.11.1.149-170

The Album of the Ljubljana Noble Society of St Dismas (hereinafter the Album) in the Archive of the Republic of Slovenia (ref. AS 1073, I/1) is not an emblem book in the proper sense of the word, yet it contains the richest and most refined collection of hand-painted emblems ever produced on Slovenian territory. ${ }^{1}$ It is a kind of memorial book of the Ljubljana Noble Society of St Dismas (hereinafter St Dismas Society) or the Academy of the United (Academia Unitorum) as they called themselves, displaying the coats of arms, emblems and important data of their members. The book with exquisite full-page illuminations is the most important illuminated manuscript of the Baroque era that survives in Slovenia. ${ }^{2}$ The origins of Theatrum Memoriae Nobilis ac Almae Societatis Unitorum (hereinafter, Theatrum Memoriae), as the original title of the Album reads, ${ }^{3}$ go back to 1688 when it was decided to found St Dismas Society and create a book that would serve as a permanent memory of the illustrious members and their deeds. In the long span of more than a hundred years, from $1689^{4}$ to 1801 ,

1 The emblems in the Album are actually not emblems in the strict sense of the word but imprese because they lack the epigram and are composed only of a pictura and a motto. Sometimes even the traditional form of the impresa with the pictura clearly framed in the cartouche and the motto beneath or above it is replaced by an atypical, so-called "open emblem", where the whole miniature is composed as an emblem and the motto is inscribed in it. Because in the studies of the Album of the Ljubljana Noble Society of St Dismas the designation "emblem" is used as a standard, we follow suit.

2 The Album of the Ljubljana Noble Society of St Dismas contains curricula vitae and full-page illustrations with the emblems and coats of arms of the society's members which were commissioned whenever a new member joined the Society. Since 2001 a Facsimile with complete transcription is available: The Album of the Ljubljana Noble Society of St Dismas, 1688-1801, vols. I-II, Ljubljana 2001. Volume I includes transcription of the original text, translation and materials; volume II includes studies.

3 The full title actually reads: Theatrum Memoriae Nobilis ac Almae Societatis Unitorum das ist Schau Bühne der Gedächtnuß der Adelichen und Gottseeligen Geselschafft der Vereinigten zu stätts wherenden Andenken eröffnet in der Uhralten Haubt Statt Laybach 1688.

$4 \quad$ The Society was founded on $5^{\text {th }}$ May 1688 and first inscriptions were made on $12^{\text {th }}$ September 1689. The last two members were inscribed in 1801. 
when the last members of St Dismas Society found their place in the book, a kind of memorial gallery was created that contains 182 illuminated pages with a variety of interesting emblems. Each member was obliged to participate with a miniature that usually includes his coat of arms, an emblem, his chosen member name, the date of the enrolment in the Society and his signature. The illuminations are often more complex, featuring additional allegoric figures of virtues, mythological figures and scenic elements such as an idealized landscape or - in few cases - a quite realistic countryside with a member's manor in the background of the miniature. The illustrations in the Album are the work of several painters and miniaturists of the period, including Andrej (Andreas) Trost, Bartolomej (Bartholomeus) Ramschissl, Matija (Matthias) Greyscher and Simon Tadej Volbenk Grahovar (Simon Thaddeus Wolfgang Grachower), as well as some anonymous illustrators (Cevc, 2001, 102-105).

The Theatrum Memoriae is a monument of great cultural importance because it reflects the intellectual milieu and artistic taste of Ljubljana in the period of its great rebirth as the centre of the former duchy of Carniola. The Academia Unitorum was one of the nuclei of intellectual and cultural renaissance and it paved the way for the much more famous Academy of the Industrious (Academia Operosorum) founded in 1693. Academia Operosorum was modelled on contemporary Italian academies, such as Accademia dei Gelati in Bologna. Among its members were some of the most distinguished representatives of the Carniolan nobility and intellectual elite that became promoters of scientific, cultural and artistic revival of Ljubljana and the duchy of Carniola in the early $18^{\text {th }}$ century. ${ }^{5}$

The association of Academia Unitorum in Ljubljana with Accademia dei Gelati in Bologna should not come as a surprise because its first secretary, Janez Gregor Dolničar (Johann Georg Thalnitscher) was a member of the Bologna academy as well. The same is true of his renowned uncle Janez Ludvik Schönleben (Johann Ludwig Schönleben). ${ }^{6}$ Some ideas of St Dismas Society are certainly based on the program of the Accademia dei Gelati and the Album can be compared to the similar project of the memorial book realized by the Academia Gelatorum. The comparison of the famous Memorie, imprese, e ritratti de’ signori Accademici Gelati de Bologna (hereinafter, Memorie, imprese, e

5 Some prominent members of the Society of St Dismas were indeed founders of the Academia Operosorum. Cf.: Dolinar, 1994, 35-46; Kastelic, 2001, 35-40; Lavrič, 2003, 27-30. For Academia Operosorum and its role in the development of Ljubljana as the cultural and intellectual centre of Carniola with special regard to Rome as a model, see: Vidmar, 2013.

6 Johann Ludwig Schönleben (1618-1681), Slovenian historiographer and one of the leading intellectuals of the period, studied in Vienna, Graz and Padua. In Padua he was invited to accept the post of the university professor of theology but refused it and took the post of the Dean of the Cathedral Chapter in Ljubljana instead. He was active in different fields of science and culture, an internationally acknowledged scholar and member of several Italian academies. For concise information on Johann Ludwig Schönleben see: Slovenski biografski leksikon s. v. Schönleben, Janez Ludvik (http://nl.ijs.si:8080/fedora/get/sbl:2841/VIEW/). 
ritratti), published in Bologna in $1672^{7}$ and Theatrum Memoriae clearly shows that the latter was modelled on the Italian predecessor (Germ, 2011, 33-40). There are of course considerable differences: in the Album there is just a single portrait, namely that of the founder of St Dismas Society, Baron Wolfgang Sigmund von Künpach, the curricula vitae are shorter and written for the early members only, ${ }^{8}$ the literary or scientific works of the members are not listed etc. The most obvious difference is of course the media - while Memorie, imprese, e ritratti is a printed book decorated with engravings only, the Album is a manuscript with lavish full-page illuminations in colour and gold. The illustrations are far more complex (both visually and iconographically) and it is their iconography that is of special interest to the present article.

The question of possible sources for the iconography of emblems in the Album has not yet been systematically addressed. Because of the variety and large number of emblem books that might have served as an inspiration, it is too early to speculate on all the possible sources. Actually both the analysis of emblems in the Album and their origin in the context of St Dismas Society show that it would be wrong to search for direct models or prototypes: the members of the Society were looking for original, individualized emblems, designed exclusively for them. Copies or reproductions of the already existing emblems were unacceptable. At the same time the members expected the symbolic elements of the pictura to be well established in the tradition of emblems so that a learned reader could easily understand the meaning of their personal emblem. Bearing in mind these fundamental premises, the focus on potential sources becomes clearer and at the present state of research at least one referential emblem book should be pointed out, namely the famous Mundus Symbolicus, a great encyclopaedia of Renaissance and Baroque emblems, written by the Italian scholar Filippo Picinelli.

Mundus Symbolicus was tremendously popular among intellectual elite and artists of the Baroque era: the book was first published in 1653 as Mondo Simbolico, ${ }^{9}$ but it was soon translated into Latin (1681 in Cologne by Augustin Erath ${ }^{10}$ ) and a

7 The Memorie, imprese, e ritratti de' signori Accademici Gelati de Bologna, a memorial book with representations of the illustrious members of the Academy (their curricula vitae, scientific or literary works, their portraits, coats of arms and impresses), is considered one of the most important Baroque emblem books. The complete version is available online: http://www.archive.org/details/ memorieimpreseer00acca.

8 After the death of the first secretary of the Society, Janez Gregor Dolničar in 1719, the curricula vitae were not written anymore and the Album is not completed in the way it was planned.

9 Mondo simbolico : o sia vniversita d'imprese scelte, spiegate, ed' illvstrate con sentenze, ed eruditioni sacre, e profane stvdiosi diporti dellabbate D. Filippo Picinelli... Francesco Mognagha, 1653 Milano.

10 Mundus symbolicus: in emblematum universitate formatus, explicatus, et tam sacris quàm profanis eruditionibus ac sententiis illustratus : subministrans oratoribus, praedicatoribus, academicis, poetis \& $c$. innumera conceptuum argumenta / idiomate Italico conscriptus a reverendissimo domino D. Philippo Picinello ... justo volumine auctus et Latinum traductus a R. D. Augustino Erath, Hermann Demen, Köln 1681. 
series of new editions appeared both in Italy and Germany. Many members of St Dismas Society studied at Italian and German universities and it is very likely that at least some of them got acquainted with the book while staying abroad. It is also highly probable that copies of Mundus Symbolicus were brought to Ljubljana already before the end of the $17^{\text {th }}$ century. There are five volumes today to be found in public libraries in Slovenia. One of them was (and still is) in the first public library in Ljubljana, today the Seminary Library. ${ }^{11}$ The library was founded on the initiative of the members of the Academia Operosorum by the highest ecclesiastics of the Ljubljana Diocese: Bishop Žiga Krištof Herberstein (Sigismund Christoph von Herberstein), the Cathedral Provost Janez Krstnik Prešeren (Johann Baptist Prescheren) and Dean of the Cathedral Chapter Janez Anton Dolničar (Johann Anton Thalnitscher) in 1701. Majority of the members of the Academia Operosorum were also associates of St Dismas Society. ${ }^{12}$ The donator of Picinelli's book, kept in the Seminary Library, is not known nor is there any record about the date of acquisition. However there is little doubt about its importance as a stimulus for creators of emblems in the Album. The analysis of the emblems makes evident correlations that can hardly be coincidental. It is very likely that the creators of the emblems had some other emblem books at their disposal and used them as a source of inspiration. Speaking about authorship of emblems in the Album it seems that a great majority of concepts for individual emblems created in the first three decades (1689-1719) can be attributed to Janez Gregor Dolničar, the most active member and the first secretary of St Dismas Society. His Concept book with 83 sketches of emblems is still preserved in the Seminary Library in Ljubljana. ${ }^{13}$ The sketches show that Dolničar was an inventive author who did not copy emblems form the existing emblem books. On the contrary: he envisaged an original series of emblems with the clearly expressed consistence in both design and symbolic meaning. The pictures are all framed by an oval cartouche with inscription bands: usually a shorter one with the member's chosen name below the cartouche and a longer one with a motto above it. Dolničar also insisted that all emblem pictures contain the symbol of St Dismas Society - a beautifully shaped

11 I would like to thank Dr. Luka Vidmar, an expert on Baroque art and literature, for the information about the Cologne edition of Mundus Symbolicus (published in 1694 by Hermann Demen in Köln) in the Seminary Library of Ljubljana. Besides the copy in the Seminary Library, there is one in the National and University Library of Slovenia, one in the Library of the National Museum of Slovenia, one in the Library of the Faculty of Arts at the University of Ljubljana and one at the Capuchin Convent in Škofja Loka.

12 It should be emphasized that the Diocese Provost J. K. Prešeren and the Dean of the Cathedral Chapter J. A. Dolničar were members of both academies. It was them (together with Bishop Herberstein) who took the decision to found the library and decided to donate the books of their private libraries as an example to be followed by the members of the academies.

13 The precise date of the Concept book (123 folios, sign. Rokopis 6) is not known, but it is likely that it had been created in the span of several years between 1689 and 1719. The folios with emblem sketches are probably the oldest part of the book (Baraga, 2001, 235). 
red heart. In most of his designs a stylised heart has a prominent role both in the composition and the iconography of the pictura. Dolničar's Concept book reveals his intimate knowledge of emblematic tradition and there is no doubt that he must have been able to study some of the most popular emblem books of the period. This is proved by an interesting observation: although his designs are original creations, there nevertheless appear elements (both conceptual and formal) that are clearly inspired by the already existing emblems.

In addition to Dolničar's role as an inventor of emblems one should not forget that the first author of the illuminations in the Album, Andrej Trost, ${ }^{14}$ who transformed the sketches into beautiful miniatures, was also well versed in design of emblems. Trost worked for Baron Janez Vajkard Valvasor (Johann Weichard Valvasor) for more than a decade and was familiar with many books of emblems in Valvasor's library. ${ }^{15}$ He designed some original emblems while working for Valvasor. More interesting still is the fact that Trost's miniature animal compositions in the decorative borders of illustrations of two early prints by Valvasor originate from several emblem books owned by the Baron. ${ }^{16}$ The collaboration of the highly educated and ambitious patron with an artist who himself was well versed in the art of Baroque emblems, resulted in the original and most exquisite series of emblems that adorns the Album.

As already mentioned, Mundus Symbolicus is not the only source for emblems in the Album, but its role appears to be vital owing to the encyclopaedic character of the book. While most of Renaissance and Baroque emblem books offer series of emblems in their traditional form (the pictura, the motto or lemma and the epigram or carmen), the concept of Picinelli's book is completely different. It is, strictly speaking, not a book of emblems but a huge encyclopaedia of symbolic meanings of emblematic subjects and themes, organized as a dictionary of symbols. Plants, animals, elements, objects, characters etc. are presented in separate chapters where the author discusses their many

14 Andrej Trost (c. 1643-1708), the leading copperplate engraver in Carniola in the last quarter of the $17^{\text {th }}$ century, was head of Valvasor's printmaking workshop all from its inauguration in 1678 until 1688 and participated in all graphic ventures of Valvasor. See: Lisac and Reisp, Trost, Andrej, in: Slovenski biografski leksikon IV, Ljubljana 1971, pp. 186-187; http://www.slovenska-biografija.si/ oseba/sbi724835/.

15 In Valvasor's library there are Emblematum liber by Andrea Alciati, Symbolicarum quaestionium de universo genere by Achille Bocchi, Emblematum liber by Jean Jacques Boissard, Emblemata by Hadrian Junius, Speculum imaginum veritatis occultae, exhibens symbola, emblemata, hieroglyphica, aenigmata by Jacob Masenius, Nucleus Emblematum Selectissimorum by Gabriel Rollenhagn, Emblemata by Joannes Sambucus, and Emblemata Psycho-ethica by Nicolaus Taurellus. We should also mention the Hieroglyphica by Horapollo as well as the Hieroglyphica by Pierio Valeriano (Germ, 2015, 110).

16 By skillfully recreating many emblem pictures in the decorative borders for Dominicae Passionis Icones (1679) and Theatrum mortis humanae tripartitum (1682) Trost proved to be a creative master with great interest in Baroque emblematics (Germ, 2015 Archetypa studiaque, 7-16; Germ, Theatrum mortis, 2015, 88-109). 
meanings, significations and connotations in the context of Renaissance and Baroque emblems. Picinelli believed (and clearly expressed it in the preface of his book) that everything in this world has deeper significance, a hidden symbolic meaning a man should try to decipher in order to better understand the world and God who created it. Picinelli's profound erudition and knowledge of emblematic tradition enabled him to produce a fascinating overview of the symbols used (or newly created) by the authors of the most famous Renaissance and Baroque emblem books. Mundus Symbolicus is a compilation of emblems (actually their descriptions) that served both patrons and artists as a sort of handbook: anyone who was searching for different symbolic meanings of an elephant, a bee, a rose, an apple tree, a torch, a sword, a lute etc. that appear in Renaissance and Baroque emblem books, was able to find systematic and illustrative explanations neatly arranged in thematic chapters and set alphabetically. That is precisely what many of the emblem lovers of the period were looking for and the great popularity of Picinelli's book with its numerous editions proves it. ${ }^{17}$

Mundus Symbolicus was in many ways an ideal handbook for the designers of emblems in the Album. The members of St Dismas Society were looking for individualized emblems, something freshly designed exclusively for them and in accordance with their specific character as expressed by the chosen member name. At the same time they expected the symbolic elements of the pictura to be well established in the tradition of emblems so that a learned reader could understand their personal emblem without a problem. Whenever a patron was to decide upon his personal emblem, with Mundus Symbolicus at hand he was able to choose among a vast variety of already existing symbolic topics and emblem prototypes that could serve as a potential model or inspiration. With the help of a skilled painter a patron was free to remodel the described emblems according to his own ideas or use them as a starting point of the creation of something completely new. As proved by the emblems in the Album, Andrej Trost and his followers were talented masters able to create a variety of original images according to the ideas of their patrons, skillfully balancing between the established pictorial tradition and innovation. The fact that Picinelli's book provides a multitude of descriptions and just a few actual depictions of emblems was indeed a stimulus for artists to create their own visual interpretation. The analysis of the emblems in the Album confirms that even when a patron opted for a wellknown emblem, the painter rarely repeated conventional composition. In spite of the possibility to simply copy the picture from Mundus Symbolicus or any other emblem book, the authors of the emblems in the Album introduced at least some modification

17 The encyclopaedic character of the Mundus Symbolicus is evident also in the organization and form of the Contents, which takes up far more space than usually because it is rendered in six languages. Besides the Latin as lingua franca of the intellectual elite and Italian as the language of the author, all the entries in the Contents are translated into Spanish, French, German and Dutch as well. 
with a specific symbolic meaning connected to the principles of St Dismas Society and the character of a member.

To demonstrate that Mundus Symbolicus served as an important source of inspiration, it is best to look at those emblems in the Album where only minor alterations were made in relation to the prototype in Picinelli's book. Let us examine the emblem of Janez Štefan Florjančič (Johann Stephan Floriantschitsch, Album, fol. 73r).

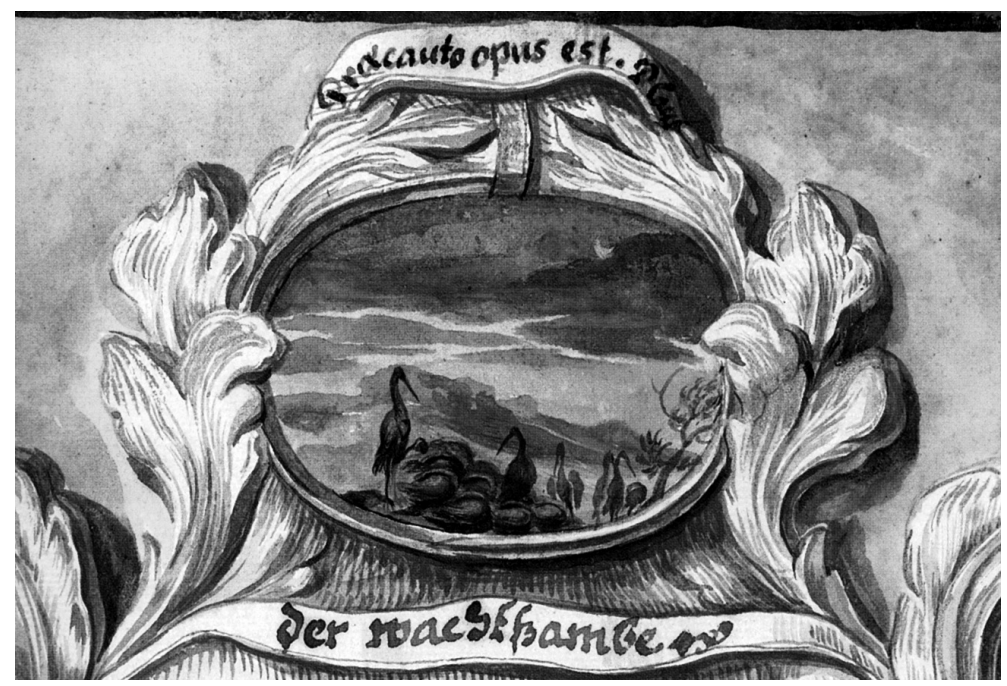

Fig. 1: Andrej Trost, The emblem of Janez Štefan Florjančič (detail), 1693, The Album of The Ljubljana Noble Society of St Dismas, Archive of the Republic of Slovenia, Ljubljana, AS 1073, I/1, fol. 73r.

In the pictura a few miniature birds are depicted in the landscape; their silhouettes are simplified to the point where it is not easy to identify the species. In older studies of emblems in the Album they are described as herons (Kastelic, 2001, 140). However, because of the fact that the most prominent of the birds, the one depicted closest to the viewer, is standing on one leg only and is holding a pebble in the claws of the other, they can definitely be identified as cranes. A crane with a stone is a settled image in European art and especially in the emblematics. It stands for vigilance (vigilantia), caution (cautela) or prudence (prudentia). ${ }^{18}$ In the case of Florjančič, the interpretation

18 When Pliny the Elder (Natural History, X, 30) presented cranes as the most watchful birds because they posted sentries during the night, and particularly by describing their intelligent manner of keeping the guarding birds awake with the help of a stone, the idea started to take root in encyclopaedic literature as well as in visual arts. In medieval bestiaries this is a standard way of depicting a crane and it has a clear allegorical meaning: besides vigilance and prudence it also symbolizes devotion to the task and faith in Christ. The story was known in the Renaissance as well, and Leonardo da Vinci mentions it in his notes on animals or "Bestiary", but he also further elaborates the allegorical meaning and presents the crane as an allegory of Fidelity and Loyalty. Cesare Ripa in Iconologia describes the personification of Vigilanza as a woman with a crane by her 
is additionally confirmed by the motto Praecauto opus est (Precaution is called for) and the chosen member name Der Wachsame (The Wakeful One), both of them suggesting the proverbial watchfulness of the cranes (Germ, 2009, 300).

Depictions of the crane as the symbol of vigilance in emblem books may differ, although a single bird with a pebble in the claw is prevalent. Images of a whole flock of cranes, as in the case of the Album, are scarce indeed. One of the rare examples of a picture with a group of cranes is found in Mundus Symbolicus (Picinelli, 1694, 304). The author of the illustration, Johann Heinrich Löffler Junior decided to represent a group of sleeping cranes and a vigilant bird with a stone in the claws watching over them from a hummock in the centre of the composition. Löffler's cranes are resting in a carefully designed landscape with the hills in the background - the master engraver almost managed to transform a simple emblem picture into a miniature piece of landscape painting.

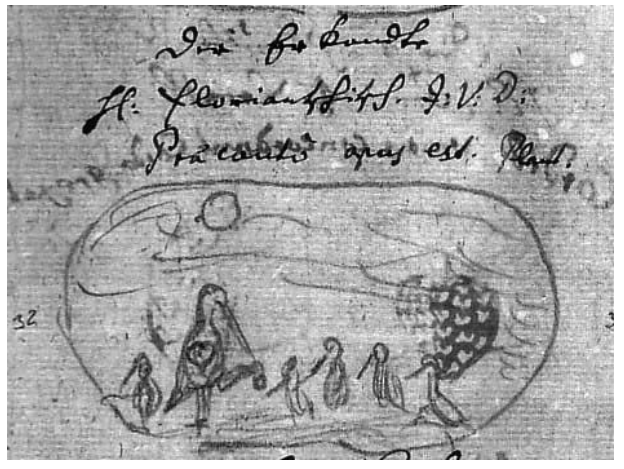

Fig. 2: Janez Gregor Dolničar, The sketch of the emblem of Janez Štefan Florjančič, 1689-1693, Dolničar's Concept book, No 32, Seminary Library, Ljubljana, manuscript 6.

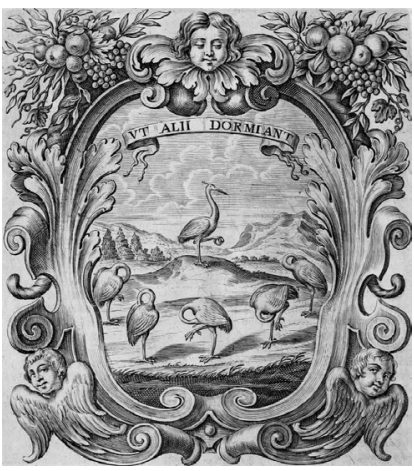

Fig. 3: Johann Hinrich Löffler Junior, Emblem No 422, Filippo Picinelli, Mundus Symbolicus, Cologne 1694, p. 304.

In Dolničar's Concept book there is a sketchy study for an emblem reproducing the same motive with only minor alteration in the composition (Dolničar, No 32). The number of the birds is the same as in Löffler's engraving but the watch bird is brought forward into the first plan and is therefore considerably bigger. The true novelty is a big heart full of tiny hearts on the right side of the composition. By looking carefully one can observe that the guarding bird also has a miniature symbol of the heart on its chest. The big heart filled with smaller hearts is an established symbol of St Dismas Society, a fact pointed out by Dolničar in the preface to the Album. ${ }^{19}$ The sentinel crane

side. The impact of Ripa's Iconologia on Baroque emblematics was huge and a crane with a pebble in its claws became a widespread symbol of watchfulness and prudence in European art.

19 In the explanation of the painted allegory of the Theatrum memoriae at the very beginning of the Album (fol. 3r) Dolničar writes that the big heart consisting of 26 little hearts represents the Society 
with a heart on the chest obviously represents Florjančič - The Wakeful One - as a vigilant guard of his colleagues.

The painted version of the emblem by Andrej Trost is a fine example of an original modification of the prototype. It also sets a standard which was not only repeated by Trost himself but later on followed by other masters as well. Trost designed a landscape similar to the one created by Löffler, only more picturesque and with much finer atmosphere. The darkening sky with a pale moon and a few early stars indicate the nightfall. On the horizon there is still some remaining light. The cranes are more naturally placed in the landscape and only the sentinel bird is emphasized in the tradition of emblem pictures. As a painter Trost obviously found Dolničar's idea of a big heart set in the landscape somehow awkward and replaced it with a small tree. Such a prominent symbol of St Dismas Society could have underlined the emblematic message of the pictura but it would definitely have spoiled the composition. However, Trost readily embraced a much subtler idea of a tiny heart on the breast of the sentinel bird. It still sends a clear symbolic signal while remaining in complete harmony with the concept of the painted scene. The genesis of the emblem picture in the Album in relation to the Mundus Symbolicus is transparent enough: while Dolničar, who was primarily concerned with the symbolic meaning, took over only the basic idea of the flock of cranes in the landscape and transformed Löffler's composition by adding the symbols of St Dismas Society, Trost as an artist beautifully balanced the new symbolic focus and the pictorial concept of the birds taking rest in the open landscape. Florjančič as the patron was pleased with the result as, obviously, was Dolničar, who didn't insist on the idea of a big heart in the landscape.

In the context of Mundus Symbolicus as a source for the iconography of emblems in the Album it should be stressed, however, that as compelling as the thesis of Florjančič's emblem being modelled on the picutra of the Löffler's composition might be, it can only be accepted because the symbolic messages of both emblems are closely related as well. Florjančičs idea of a vigilant member of the Society, watching over his companions, is actually identical to the message of the emblem in Picinelli's book where the sentinel bird keeps guard while the other cranes are sleeping peacefully. To exclude any doubt about the meaning of the Löffler's picture, the motto reads: "Ut alii dormiant".

The emblem designed for Baron Ferdinand Apfaltrer (Album, fol. 337r), represents another, actually more conventional process of creation of emblems in the Album. The pictura of Apfaltrer's emblem shows a hedgehog under the apple tree full of ripe fruits, carrying many apples on his back.

and its 26 members: "Dann so ist an diesem Theatro zu oberst das Sünbildt oder Symbolum diser Geselschaft Unitorum oder der Verainigten zubetrachten, welches da ist ein grosses, von 26 anderen zusamben gefüegtes Herz... Die 26 Herzen aber deuten an die Zahl der Einverleibten (Album, fol. 64). 


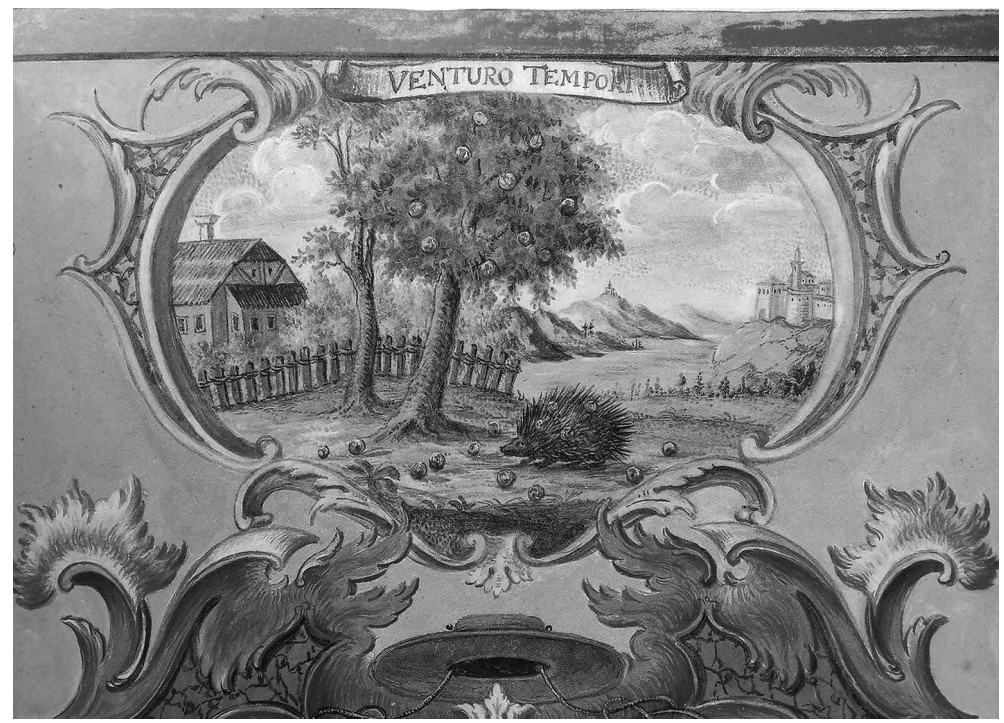

Fig. 4: Simon Tadej Volbenk Grahovar, The emblem of Ferdinand Apfaltrer (detail), 1752, The Album of The Ljubljana Noble Society of St Dismas, Archive of the Republic of Slovenia, Ljubljana, AS 1073, I/1, fol. 337r.

The animal and the tree are set into an idyllic countryside with a farmhouse on the left, a lake surrounded by the hills, and a castle on the hill in the background. The motto on the script band reads Venturo tempori (For the future). Under the cartouche with the image is a band with the Baron's chosen member name Der Vorsehende (The Provident One). The image, the motto and the member's name form a clear symbolic message: the noble academic is presented as a wise man, forward thinking like a prudent hedgehog, saving goods (apples) in the times of plenty (autumn) for the more austere moments (winter) that are coming. Since the antiquity a hedgehog (or sometimes a porcupine) carrying the heavy burden of fruit (usually grapes) into his den represents prudence, forethought and wisdom, although it can denote quite the opposite meanings as well. ${ }^{20}$ In the case of Apfaltrer the motto and the member's name leave no doubt about the interpretation of the emblem. Emblem books seldom feature images of the hedgehog with fruit on its back - in fact there are surprisingly few authors who included the animal with its fruit burden into their emblem book. In the rare cases when such an emblem

20 Due to different versions of the hedgehog story in the Physiologus the medieval interpretation of hedgehog's behaviour is often negative. The animal usually represents the devil that steals the grapes from the vineyard of a good Christian - that is, robs a man of his spiritual fruits and virtues. Such an interpretation ad malam partem might also be stimulated by the fact that in the Bible a hedgehog is connected with the image of God's wrath and the devastation of Babylon: "And I will make it a possession of the hedgehog, and pools of water" (Isaiah 14:23). 
does appear, it is grapes and not apples that the little beast is carrying. One could reasonably argue that Baron Apfaltrer opted for apples because they allude to his family name (der Apfel is an apple in German) and an apple tree is a heraldic symbol of the Apfaltrer family. The folios dedicated to other members of the family also include apples or an apple tree and the symbolism is quite obvious. ${ }^{21}$ However, it should be noted that Mundus Symbolicus includes several descriptions of a hedgehog carrying fruit and that one of them is even accompanied with the illustration of the little fellow with apples on its back. ${ }^{22}$ In Picinelli's book the emblem with a hedgehog taking the fruit into its den is accompanied by the motto "Venturi providus aevi" (Picinelli, 1694, 389). The message of the emblem in Mundus Symbolicus and the one in the Album are practically the same. There is even a sophisticated wordplay: the meaning of Apfaltrer's "Venturo tempori" is an equivalent for "Venturi aevi", while his chosen member name "The Provident One" (providus in Latin) literally completes the message of the motto in the emblem described by Picinelli: "Venturi providus aevi".

The emblem of Baron Franz Anton Moscon (Album, fol.272r) is also very interesting in the context of the Album in correlation to the Mundus Symbolicus. In earlier studies there was quite an ambiguity regarding the interpretation of the bird, sitting in the nest amidst the waves in the pictura of Moscon's emblem. The identification of the bird as a duck was proved wrong and now there is no doubt that the bird in question is actually a halcyon, usually identified as a kingfisher - Alcedo Atthis (Germ, 2009, 308). In antiquity it was believed that the halcyon (or alcyon) lays its eggs in a floating nest during the so-called halcyon days around the winter solstice. The motto: Mens immota inter motus (Untroubled spirit in time of trouble) as well as Moscon's member name Der beständing Bleibnende (The Constant One) are clearly alluding to the constancy and integrity even in the times of trouble and distress. Just as (according to the tradition) the halcyon remains undisturbed while laying eggs in its nest on the waves, so a man of moral integrity should remain constant in his beliefs and deeds regardless of the circumstances. $^{23}$

21 See the emblems of Volf Herbart Apfaltrer (193r), Janez Sigfried Apfaltrer (211r), Jožef Leopold Apfaltrer (291r), Sigmund Ferdinand Apfaltrer (232r) and Janez Ignac Apfaltrer (304r).

22 It illustrates the emblem No 430 with the motto "Nil deferet intro". The engraving can be found in the original edition of Picinelli's book (Mondo simbolico, 1653) and early editions prior to 1681 .

23 Halcyon is first described by Aristotle who writes that the bird builds a nest on the waves of the sea, which for the time remains calm (History of Animals, IX, 14; V, 8). Pliny the Elder repeats the opinion of Aristotle (Natural History, X, 90-91) and so does Aelian (On the Characteristics of Animals, IX, 17). Ovid relates the story of halcyon's nesting on the high seas to the myth of Alcyone, the daughter of Aeolus, the god of winds. In Metamorphoses (XI, 410-748) he deals in extenso with the subject and states explicitly that Aeolus retains the winds and the storms for seven days, so that little chickens his "grandchildren" - could safely be hatched. 


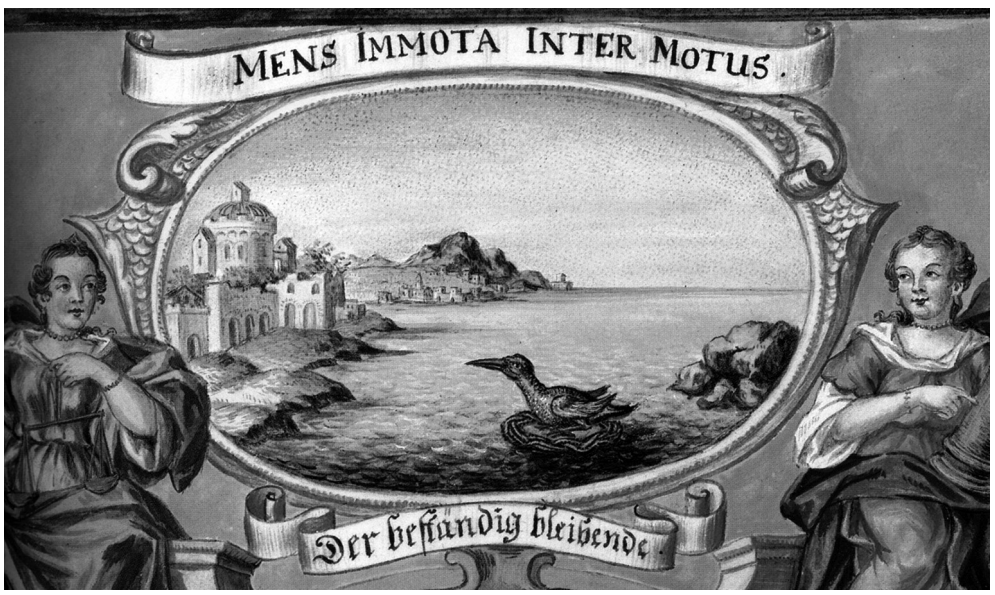

Fig. 5: Simon Tadej Volbenk Grahovar, The emblem of Franz Anton Moscon (detail), 1739, The Album of The Ljubljana Noble Society of St Dismas, Archive of the Republic of Slovenia, Ljubljana, AS 1073, I/1, fol. 272r.

A bird nesting in the open sea as depicted in the Album is not easily found in Renaissance and Baroque emblematics. According to Henkel-Schöne $(1967,840)$ the only example of a halcyon nesting on the sea waves is an engraving in the Schoonhove's Emblemata. ${ }^{24}$ Depictions in other emblem books follow the tradition of Alciati's Emblematum liber (1531, embl. B1v) where a halcyon is shown seated in the nest made on a small rock or tiny island in the sea and not directly on the water surface. The illustrator of the Emblematum liber was obviously ignorant of the established tradition of written sources, where the "fact" of nesting directly on the sea surface is continuously repeated. The author of the engraving indeed overlooked the very epigram he was to illustrate. ${ }^{25}$

The inaccurate illustration persists in all of the later editions of Emblematum liber and is even repeated in several other emblem books. Simon Grahovar, the author of Moscon's emblem, didn't follow the established visual path but depicted a halcyon

24 Emblemata Florentii Schoonhovii I. C. Goudani Partim Moralia partim etiam Civilia ... published by Andreas Burier, Gouda 1618. The illustrations are by Crispijn van de Passe the Younger.

25 Alciati's verse is clear enough on that matter:

Grandibus ex spicis tenues contexe corollas,

Quas circum alterno palmite vitis eat.

His comptae Alcyones tranquilli in marmoris unda

Nidificant, pullos involucresque fovent.

Laetus erit Cereri, Baccho quoque fertilis annus,

Aequorei si rex alitis instar erit.

(Weave pliant garlands out of luxuriant stems, around which winds a vine with interwoven shoots. With these, the crested halcyons build nests on the swell of a tranquil ocean, and nurture their fledglings. The year will be joyful for Ceres and fertile for Bacchus too, if the monarch resembles this sea-bird.) 
nesting directly on the surface of the sea as described in several sources. Theoretically it is possible that he had seen the illustration in the Schoonhove's Emblemata with a halcyon in the floating nest on the sea. However, this is not very likely to be the case: Schoonhove's book was not as universally popular as some other emblem books (only four editions are documented in the $17^{\text {th }}$ century) and there is no evidence that the book was available in Carniola in the second half of the $17^{\text {th }}$ century or in the first half of the $18^{\text {th }}$ century. (It is also not to be found in an inventory of any of Slovenian libraries.) On the other hand, Mundus Symbolicus is quite likely to be the actual source. Even more so because Picinelli discusses the halcyon in extenso: he describes 13 different emblems with the curios bird, offering several interpretations. In one of them a halcyon in the nest amidst the waves is interpreted as a symbol of a fearless and upright spirit (animus imperteritus). The bird is therefore an image of a just man who does not fear the storms of life, but stays tranquil in his firm trust in God (Picinelli, 1694, 258). The message is very close to the idea of Moscon's emblem, where the Baron - The Constant One symbolically impersonates an untroubled spirit in the time of troubles.

In Picinelli's book there is no illustration of the halcyon, and Grahovar was free to create an image according to his own and his patron's wishes, on the basis of written description only. This might be the explanation why the bird is depicted correctly, nesting directly on the seasurface and not on a rocky island as in the great majority of emblem books inspired by Alciati's Emblematum liber. Yet, there is an additional circumstance, very interesting in regard to Moscon's emblem. As already said, it is unlikely that Grahovar or his patron were aware of the illustration in Schoonhove's book. But they might have been able to see an emblem with a correctly depicted halcyon nesting directly on the sea waves in the book published by their compatriot Jožef Matija Prešeren (Joseph Matthias Prescheren) in 1728. J. M. Prešeren was a protégé of Janez Krstnik Prešeren (a nephew of the more famous uncle of the same name, the already mentioned member of St Dismas Society and the first president of the Academia Operosorum). Jožef Matija Prešeren studied in Vienna where he published Idea sapientis, ${ }^{26}$ a treatise dedicated to his patron. ${ }^{27}$ The book on moral philosophy, ethics and politics, embellished with beautiful emblems, is actually a blatant example of plagiarism: it is an exact copy of the work by Anton Vanossi (Antal Vanossy), published four years earlier by the same publisher Maria Theresa Voigt. ${ }^{28}$ Even the engravings and the page layout are precise

26 Idea sapientis theo-politici, seu Tripartita morum philosophia ethica, politica, oeconomica, summaria methodo comprehensa, problematicis quositis, et emblematis illustrata, dum in archi-ducali \& academico Societatis Jesu Gymnasio Labaci philosophiam suam publicè propugnaret, eruditus ac perdoctus dominus Josephus Mathias Preschern, Carniolus Rottmansdorffensis preside r.p. Joanne Baptista Mayr... published by Maria Theresa Voigt, Vienna 1728.

27 In the bibliographical note of the example held in National and University Library in Ljubljana, the authorship is wrongly attributed to his patron Janez Krstnik Prešeren.

Idea sapientis theo-politici, id est, Tripartita morum philosophia ethica, politica, oeconomica: summaria 
reproductions of the original book by Vanossi, the only differences being the title page, the new coat of arms (the coat of arms of Jožef Matija Prešeren's patron) and a new preface with a laudatory dedication to Janez Krstnik Prešeren. It seems that at the time the falsification was not exposed (at least not in Ljubljana). ${ }^{29}$

Putting the story of plagiarism aside, Idea sapientis is interesting in the context of this article because of the emblem with a halcyon nesting on the sea depicted in a similar way as in the emblem of Baron Moscon. The composition of pictura in Idea sapientis is evidently less sophisticated than the one created by Grahovar for the Album. One can only speculate on the possibility that the painter and his patron were familiar with the emblems in Idea sapientis. Grahovar was certainly capable of creating an original picture on the basis of a written description, provided by the explanation of emblems in Mundus Symbolicus. There was no need for a painter of his skill to look for a model. On the other hand - theoretically at least - the emblem in Idea sapientis could have served as an inspiration, a sort of starting point for the far more elaborate design by Grahovar. However, from the iconographic point of view the premise that Picinelli's book had been the initial source of inspiration stands on firm ground. Needless to say that in the process of developing emblems in the Album, it was the client who decided on both the concept and the basic design of the emblem while the artist was asked to find an appropriate visual solution and eventually suggest some refinement. It is the symbolic message that was invariably the starting point and the decisive criterion in the process. As already demonstrated, the meaning of the emblem described in Mundus Symbolicus is very close to the emblem in the Album. The one in Idea Sapientis, however, has nothing in common with the idea of Moscon's emblem. It represents the concept of the reign of the Prince who is cautious and alert even in the time of peace, because it is bound to be short-lived (like the halcyon days) and troubles are never far away. Even during the peaceful reign a prudent Prince fears hidden perils and therefore "dislikes the long periods of peace as much as war" ${ }^{30}$

methodo comprehensa, problematicis quaesitis \& emblematis illustrata ... published by Maria Theresa Voigt, Vienna, 1724. Vanossi's book was published again the same year with a different title page on the occasion of doctoral promotion of Leopold Sippl (with Vanossi presiding) and for similar occasions also in 1727 and 1728. However, the authorship was never disputed, while in the case of M. J. Prešeren Vanossi is not mentioned at all.

29 In the entry on the Prešeren family in the Slovenski biografski leksikon, the book is still described as a published doctoral dissertation of Matija Jožef Prešeren. http://www.slovenska-biografija.si/rodbina/ sbi461400/..

30 Alcyonea mihi suspecta malacia ponti est, Nam coquit atroces tum maris ira minas. Et timeo regnis nimium, fera damna, quietis: Nec diuturna mihi pax, neque bella placent. (Idea sapientis, 1728, 290) 
The examples of emblems made for Florjančič, Apfaltrer and Moscon illustrate different strategies in developing original individual emblems on the basis of established tradition and using a very popular encyclopaedia of emblems as a source of inspiration. In the Album there are other examples that demonstrate the popularity of Mundus Symbolicus among the members of Carniolan intellectual elite united in the Academia Unitorum. However, more important than citing additional examples is to recognize the mindset of the creators (both patrons and painters) and the principles behind the creation of emblems. Since the members desired original and personalized emblems, it was more convenient to rely upon Picinelli's encyclopaedic work with a huge collection of systematically arranged emblems, neatly described and interpreted. The fact that Mundus Symbolicus contains few illustrations turns out to be an asset and not a drawback for the authors of the Album. The book is a treasure-trove of ideas instigating new designs both in the sense of symbolic message and visual solutions, while the absence of illustrations prevents a simple reproduction of emblems. Due to their commitment to originality the members of the Society obviously found the traditional emblem books (where they could find prototypes including the picture) less appealing. But even in the cases when they used a traditional emblem book as a model, the creators of emblems in the Album demonstrated their inventiveness and originality.

Let us take a look at two examples to illustrate this process: the emblem created for Hans Jakob Schell (Album, fol. 93r) and the one made for Anton Gallenfels (Album, fol. 135r).

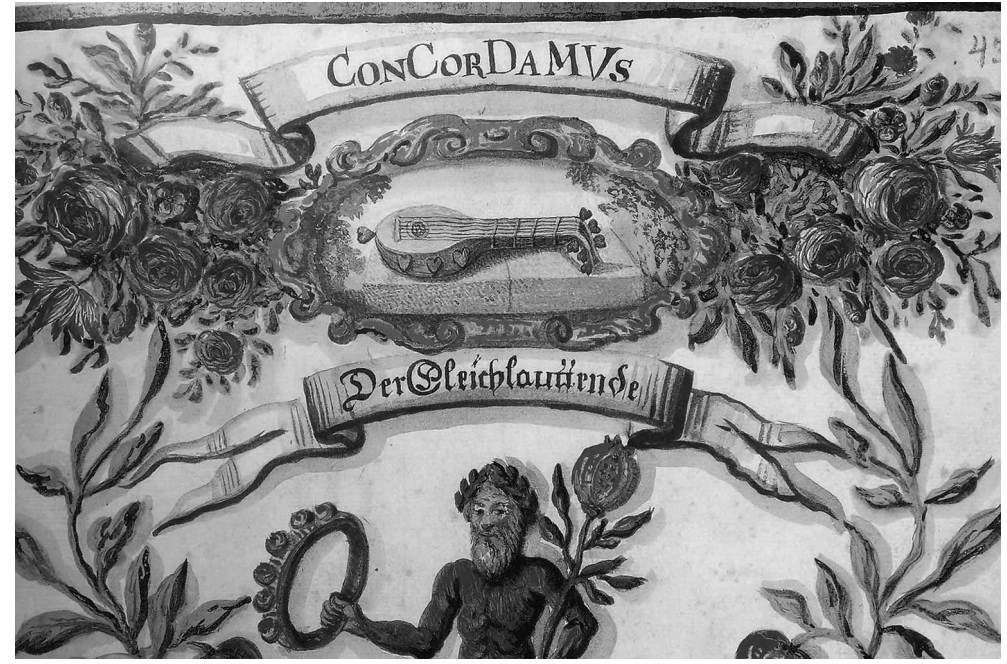

Fig. 6: Andrej Trost, The emblem of Hans Jakob Schell (detail), 1695, The Album of The Ljubljana Noble Society of St Dismas, Archive of the Republic of Slovenia, Ljubljana, AS 1073, I/1, fol. 135r. 
They were designed by Dolničar, modelled on Alciati and artistically elaborated by Trost. Looking at the preliminary designs by Dolničar in his Concept book (embl. No 42) one could assume that the author chose to imitate the pictura of Alciati's model with only minor changes of the original design. At a first glance the changes might indeed appear to be minimal both in form and iconography but they nevertheless turn out to be an inventive manoeuvre by which Dolničar creates a new emblem with an original symbolic message. In the case of Schell's emblem the composition of the pictura is quite simple: there is only a lute, a popular and frequently depicted instrument ever since Alicati introduced it into his Emblematum liber in 1531 (embl. A3r). ${ }^{31}$ In Alciati 1531 the lute is placed on an undefined wooden surface. In later editions it can be placed on a table, a bed or a sofa. In the Album it is displayed on a slab of stone, but the placement of the lute itself is insignificant from the iconographic point of view. What is worth noticing is actually a modification of the lute: it is elegantly decorated with four hearts. In addition, the six tuning pegs are shaped as little hearts. Traditionally a lute in an emblem book represents the idea of harmony and concord although the motto can express this idea in various ways. The motto in Schell's emblem reads Concordamus (We are in accord). The idea of harmony is thus explicitly associated with the harmonious union of the members of St Dismas Society. It is additionally accentuated by the member's chosen name: Der Gleichlautende (The Concordant One). The idea to choose a musical instrument as a symbol of harmony and concord (as a matter of fact, there are many other symbols that can represent this idea) seems to be yet another witty hint. It alludes to the member's family name Schell: die Schelle in German means a bell and the hand bells are to be found in his coat of arms as well.

In the pictura of the emblem, designed for Anton Gallenfels, the abbot of the Stična monastery, a reader can see a familiar emblematic scene with two jugs floating side by side down the stream.

31 It should be mentioned that the emblem with a lute appears in Picinelli's book as well. Theoretically the description could serve as a source of inspiration just as well as in the other examples presented in the article. However, it is impossible to ignore the fact that the emblem was very popular indeed and can be seen again and again in Renaissance and Baroque emblem books. Considering the huge popularity of Alciati, it is likely that in this case the emblem (in one of the many editions of Eblematum liber) actually served as the prototype. In the context of the familiarity of the Carniolan intellectual elite with Alciati's book it suffices to say that Valvasor alone owned three copies of Emblematum liber. 


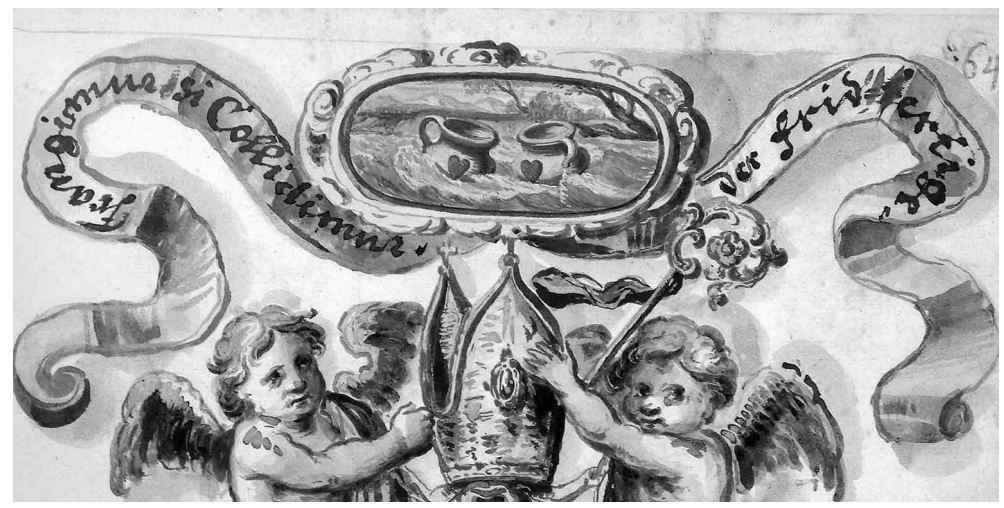

Fig. 7: Andrej Trost, The emblem of Anton Gallenfels (detail), 1702, The Album of The Ljubljana Noble Society of St Dismas, Archive of the Republic of Slovenia, Ljubljana, AS 1073, I/1, fol. 93r.

The image had again been introduced by Alciati (embl. D1r) and also appears in several other emblem books. In the original emblem by Alciati one of the jugs is made of metal, the other of clay. In Alciati's book the motto is: Aliquid mali propter vicinum malum (Something evil, from an evil neighbour). The epigram describes how the metal jug asked the earthen one to come closer, so that jointly they could withstand the rushing waters. However, the clay jar was aware of the falseness of the offer, knowing that being fragile it will perish, while the metal jug will survive. In the Album the two jugs are both made of clay and embellished with a big heart, as already in the sketch by Dolničar (Concept book, embl. No 63). The motto reads: Frangimur, si collidimur (If we collide, we shatter). As the two jugs are made of clay the collision could be fatal for both of them. But the motto is completed with the member's chosen name: Der Friedfertige (The Peaceful One). The symbolic message of the emblem thus takes on a completely new meaning: the noble Abbot does not want to hurt anybody and he cares for the "safe distance", i.e. mutual respect and appreciation. At first sight the alteration of the original picture might look unimportant and the new emblem an unimaginative reproduction. But that is far from being the case. It is actually a fine example of creative metamorphosis of an established prototype into a new emblem with original symbolic message devised to emphasize both the idea of St Dismas Society and the personal character of its member.

As the opening argument of the article claims: because of the specific context of the Album as a memorial book of St Dismas Society and a clearly articulated patrons' ambition to create original individualized emblems, it is not easy to identify the possible sources let alone detect a direct influence. There are several books of emblems to be taken into consideration and as demonstrated in the article, the famous 
Emblematum liber by Andrea Alciati was certainly among model books used by the authors of the Album. However, a detailed analysis of the emblems in the Album and thorough research of Renaissance and Baroque books of emblems show that it is actually Mundus Symbolicus by Filippo Picinelli that served as the most important source of inspiration for the emblems in the Album.

\section{References}

\section{Sources}

Andrea Alciati, Emblematum liber, Augsburg 1531.

Aelian, On the Characteristics of Animals. With an English Translation by A. F. Scholfield, 3 vols., Loeb Classical Library, Cambridge, MA 1958-1959.

Joachim Camerarius, Symbolorum et emblematum centuriae tres. I. Ex herbis \& stirpibus. II. Ex animalibus quadrupedibus. III. Ex volatilibus \& insectis ... Accessit noviter centuria IV. Ex aquatilibus \& reptilibus, Nuremberg 1590-1605.

Leonardo da Vinci, Cod. H 9r, Institut de France, Paris, in: Richter, J. P., The Notebooks of Leonardo da Vinci, XX, 1228, London 1880.

Ovid, Metamorphoses. With an English Translation by F. J. Miller, 2 vols., Loeb Classical Library, Cambridge, MA 1999.

Filippo Picinelli, Mondo simbolico: o sia vniversita d'imprese scelte, spiegate, ed' illvstrate con sentenze, ed eruditioni sacre, e profane... Milan 1653.

Filippo Picinelli, Mundus symbolicus: in emblematum universitate formatus, explicatus, et tam sacris quàm profanis..., Cologne 1681.

Pliny, Natural History. With an English Translation by H. Rackham, 10 vols., Loeb Classical Library, Cambridge, MA 1938.

Jožef Matija Prešeren, Idea sapientis theo-politici, seu Tripartita morum philosophia..., Vienna 1728.

Gabriel Rollenhagen, Nucleus Emblematum selectissimorum..., Cologne 1611.

Florens Schoonhoven, Emblemata partim moralia, partim etiam civilia..., Gouda 1618.

Theatrum Memoriae Nobilis ac Almae Societatis Unitorum das ist Schau Bühne der Gedächtnuß der Adelichen und Gottseeligen Geselschafft der Vereinigten zu stätts wherenden Andenken eröffnet in der Uhralten Haubt Statt Laybach 1688, Archive of the Republic of Slovenia, Ljubljana AS 1073, I/1

Valerio Zani, Memorie, Imprese, e Ritratti de' Signori Accademici Gelati de Bologna..., Bologna 1672. 


\section{Literature}

Baraga, F., Dolničarjeva konceptna knjiga ljubljanske plemiške družbe sv. Dizma, Uvodna pojasnila, in: Spominska knjiga ljubljanske plemiške družbe sv. Dizma 1688-1801, I (ed. Gostiša, L.). Ljubljana 2001, pp. 235-236.

Cevc, E., The Illuminated Manuscript Book of the St Dismas Society, in: The Album of Ljubljana Noble Society of St Dismas, 1688-1801, vol. II, Ljubljana 2001, pp. 99-113.

Dolinar, F. M., Od Dizmove bratovščine do Akademije delovnih v Ljubljani, in: Academia Operosorum, zbornik prispevkov s kolokvija ob 300-letnici ustanovitve, Ljubljana 1994, pp. 35-46.

Germ, T., Spominska knjiga ljubljanske plemiške družbe sv. Dizma: zgodovinski kontekst nastanka in njeni idejni vzori, Arhivi 34, 1, 2011, pp. 33-40.

Germ, M., Iconography of Emblematic Animals in the Album of the Ljubljana Noble Society of St Dismas: Readings and Misreadings, IKON Journal of Iconographic Studies 2, 2009, pp. 305-312.

Germ, M., Archetypa studiaque von Jacob Hoefnagel: Vorlage für Tier- und Pflanzenabbildungen in den dekorativen Bordüren von Valvasors Theatrum mortis humanae tripartitum, Barockberichte 63, 2015, pp. 7-16.

Germ, M., Theatrum mortis humanae tripartitum (1682) de Johann Weichard Valvasor: un livre d'emblèmes?, Stephanos 9, 1, 2015, pp. 88-109; http://www. stephanos.ru/index.php?cpub=212.

Gspan, A., s.v.: Rodbina Prešeren, Slovenski biografski leksikon, VIII, Ljubljana 1952; http://www.slovenska-biografija.si/rodbina/sbi461400/.

Henkel, A., Schöne, A., Emblemata. Handbuch zur Sinnbildkunst des XVI. und XVII. Jahrhunderts, Stuttgart 1967.

Kastelic, J., The Ljubljana Noble Society of St Dismas in Time and Space, in: Spominska knjiga ljubljanske plemiške družbe sv. Dizma 1688-1801, II (ed. Gostiša, L.), Ljubljana 2001, pp. 35-40.

Kastelic, J., Emblems in the mirror of iconography. Catalogue, in: The Album of Ljubljana Noble Society of St Dismas, 1688-1802, vol. II, (Studies), Ljubljana 2001, pp. 119-261.

Lavrič, A., Societas Unitorum - Akademija Združenih. Zgodovina ljubljanske stolne cerkve, Ljubljana 2003, pp. 27-30.

Lisac, L. A., Reisp, B., s.v.: Trost, Andrej, Slovenski biografski leksikon, IV, Ljubljana, 1960, pp. 186-187; http://www.slovenska-biografija.si/oseba/sbi724835/. 
Miklavčič, M., s.v.: Schönleben, Janez Ludvik, Slovenski biografski leksikon, X, Ljubljana 1967; http://www.slovenska-biografija.si/oseba/sbi548709/.

Smolik, M., The Members of the Society of St Dismas and their Album. Spominska knjiga ljubljanske plemiške družbe sv. Dizma 1688-1801, II (ed. Gostiša, L.), Ljubljana 2001, pp. 291-303.

Vignau-Wilberg, T., Archetypa studiaque patris Georgii Hoefnagelii, 1592: Natur, Dichtung und Wissenschaft in der Kunst um 1600, Munich 1994.

Vidmar, L., Ljubljana kot novi Rim. Akademija Operozov in baročna Italija, Ljubljana 2013.

Vrhunc, P., Simon Tadej Volbenk Grahovar (1710-1774), Zbornik za umetnostno zgodovino, n. v. 8, 1970, pp. 107-132. 


\section{Tine Germ}

\section{Emblemi v Spominski knjigi ljubljanske plemiške družbe sv. Dizma: kontekst, viri, izvirnost}

Ključne besede: Spominska knjiga ljubljanske plemiške družbe sv. Dizma, Filippo Picinelli, Mundus Symbolicus, Andrea Alciati, Emblematum liber, renesančna in baročna emblematika, ikonografija, Janez Gregor Dolničar, Andrej Trost

Avtor v prispevku opredeli vire in zglede za ikonografijo emblemov v Spominski knjigi ljubljanske plemiške družbe sv. Dizma (Dizmova kronika), hranjene v Arhivu Republike Slovenije (ref. AS 1073, I/1), ki še niso bili raziskani. Dizmova kronika je izvirna oblika spominske knjige, $\mathrm{v}$ kateri so na pretežno celostranskih miniaturah predstavljeni emblemi in imena članov družbe, njihovi grbi in podatki o vpisu v družbo. Prve miniature so nastale leta 1689 , zadnji člani pa so bili vpisani leta 1801. Kakovost iluminacij in ikonografsko bogastvo sta izjemna, tako da Dizmova kronika danes upravičeno velja za najodličnejši baročni iluminirani rokopis, kar se jih je ohranilo na Slovenskem.

Najnovejšeraziskavekažejo, da seidejain konceptdela zgledujeta povsebinsko sorodno zasnovani spominski knjigi bolonjskih akademikov Memorie, imprese, e ritratti de' signori Accademici Gelati de Bologna, izdani v Bologni leta 1672. Zaradi specifičnega konteksta nastanka Dizmove kronike so emblemi izvirne stvaritve, s poudarjeno individualizirano vsebino, kar bistveno otežuje iskanje literarnih virov in morebitnih neposrednih zgledov. Nedvomno je treba upoštevati možnost vpliva večjega števila renesančnih in baročnih emblemskih knjig, vse od inkunabule renesančne emblematike, Alciatijeve Emblematum liber (1531), do sočasnih izdaj. Raziskave zgodnjenovoveške emblematike kažejo, da je med ključnimi viri navdiha za embleme v Dizmovi kroniki popularna, enciklopedično zasnovana knjiga emblemov Mundus Symbolicus Filippa Picinellija, ki je pod naslovom Mondo simbolico prvič izšla v Milanu leta 1653. Picinellijevo obsežno delo z opisi več sto emblemov je prava zakladnica idej za nove embleme. Zdi se, da so bile klasične emblemske knjige, iz katerih bi lahko naročniki preprosto posneli uveljavljene embleme, prav zaradi želje po izvirnosti za člane Dizmove družbe manj privlačne. Analiza emblemov v Dizmovi kroniki pokaže, da tudi v primerih, ko so se naročniki zgledovali po tradicionalnih emblemskih knjigah (npr. po Alciatiju), emblemov niso kopirali, ampak so jih domiselno preoblikovali. Spominska knjiga ljubljanske plemiške družbe sv. Dizma ni eklektično delo, ki bi povzemalo obstoječe prototipe, zato se iskanje neposrednih zgledov praviloma izkaže za brezplodno. Gre za edinstveno zbirko izvirnih emblemov, ki razkriva kompleksen odnos do obstoječe tradicije in predstavlja pomemben prispevek v razvoju baročne emblematike. 


\section{Tine Germ}

\section{The Emblems of the Album of the Liubljana Noble Society of St Dismas: Context, Sources, Originality}

Keywords: Album of The Ljubljana Noble Society of St Dismas, Filippo Picinelli, Mundus Symbolicus, Andrea Alciati, Emblematum liber, Renaissance and Baroque emblems, iconography, Janez Gregor Dolničar, Andrej Trost

The article discusses the sources for the iconography of emblems in the Album of the Ljubljana Noble Society of St Dismas (Archive of the Republic of Slovenia, ref. AS 1073, I/1) that has not yet been systematically addressed. The Album is a kind of memorial book of the Ljubljana Noble Society of St Dismas or Academia Unitorum, displaying the coats of arms, emblems and important data of their members. The book with exquisite full page illuminations is the most important illuminated manuscript of the Baroque era that survives in Slovenia. Recent research shows, that the idea of the academic memorial book and its concept are modelled on the Memorie, imprese, e ritratti de' signori Accademici Gelati de Bologna published in Bologna in 1672. Due to the specific context of the Album as a memorial book of St Dismas Society and a clearly articulated ambition of the patrons to create original individualized emblems, it is not easy to identify the possible sources let alone detect the direct influence. There are several emblem books to be taken into consideration and Alciati's Emblematum liber appears to be a valuable source of inspiration. However, the research in Renaissance and Baroque books of emblems shows that it is actually Mundus Symbolicus by Filippo Picinelli (first published as Mondo simbolico, Milan 1653) which seems to be of vital importance for the creators of the Album. Since the proud members desired original and personalized emblems, it was only natural to rely upon a popular encyclopaedic work with a huge collection of systematically arranged descriptions of emblems. Picinelli's book is actually a treasure-trove of ideas instigating new designs both in the sense of symbolic message and visual solutions, while the almost complete absence of illustrations prevents a simple reproduction of emblems. Due to their commitment to originality and the respect of the principles of St Dismas Society the members obviously found the traditional emblem books (where they could see prototypes including the picture) somehow less appealing. However, even when they use a traditional emblem book such as Alciati's Emblematum liber as a model, the authors (both patrons and painters) of the Album exhibit great inventiveness and creativity and never simply reproduce a prototype. The Album thus represent a unique series of original emblems that also indicate the commitment to established tradition and occasionally reveal a direct influence of a popular emblem book as demonstrated in the article. 